Patricia Muñoz $12,3,4$

Alicia Galar ${ }^{1,2}$

Pilar Catalán ${ }^{1,2}$

Maricela Valerio ${ }^{1,2}$

Teresa Aldamiz-Echevarría ${ }^{1,2}$

Carlos Cólliga $a^{2,5}$

Emilio Bouza ${ }^{1,2,3,4}$

On behalf of the Gregorio

Marañón Microbiology-ID

COVID 19 Study Group

\section{The first 100 cases of COVID-19 in a Hospital in Madrid with a 2-month follow-up}

Article history

Received: 8 July 2020; Revision Requested: 15 July 2020; Revision Received: 16 July 2020; Accepted: 22 July 2020;

Published: 30 July 2020

\section{ABSTRACT}

Background. There are few descriptions of the clinical presentation and evolution of consecutive SARS-CoV-2 infections with a long-enough follow up.

Methods. Description of the first consecutive 100 patients with microbiologically-proven COVID-19 in a large hospital in Madrid, Spain including a minimum of two-month follow up.

Results. The median age of the patients (52\% males) was 61.5 years $(I \mathrm{QR}=39.5-82.0)$ and the median BMI was $28.8 \mathrm{~kg} / \mathrm{m}^{2}$ $(I Q R=24.7-33.7)$. Overall $72 \%$ of the patients had one or more co-morbid conditions with a median age-adjusted Charlson index of $2(I Q R=0-5.7)$. Five patients (5\%) were immunosuppressed. The most common symptoms at the time of diagnosis were fever $(80.0 \%)$, cough $(53.0 \%)$ and dyspnea $(23.0 \%)$. The median $\mathrm{O}_{2}$ saturation at the time of first examination was $94 \%$ (IQR=90-97). Chest $X$-ray on admission was compatible with pneumonia in 63\% of the cases (bilateral in $42 \%$ and unilateral in 21\%). Overall, 30\% were managed at home and 70\% were admitted to the hospital. Thirteen patients were admitted to the ICU with a median of 11 days of stay in the Unit $(I Q R=6.0-28.0)$. CALL score of our population ranged from 4 to 13 . Overall, $60.0 \%$ of patients received antibiotic treatment and $66.0 \%$, empirical antiviral treatment, mainly with lopina-

Correspondence:

Dr. Alicia Galar

Servicio de Microbiologia y E. Infecciosas

Hospital General Universitario Gregorio Marañón

C/ Dr. Esquerdo, 46

28007 Madrid, Spain

Phone: +34- 91- 58684 53/Fax: +34- 91- 5044906

E-mail: alicia.galar@salud.madrid.org

Prof. Emilio Bouza

Servicio de Microbiologia y E. Infecciosas

Hospital General Universitario Gregorio Marañón

C/ Dr. Esquerdo, 46

28007 Madrid, Spain

Phone: +34- 91- 58684 53/Fax: +34- 91- 5044906

E-mail:emilio.bouza@gmail.com vir/ritonavir $(65 \%)$ or hydroxychloroquine (42\%). Mortality, with a minimum of 60 days of follow up, was $23 \%$. The median age of the deceased patients was 85 years $(I Q R=79-93)$.

Conclusions. We found a high mortality in the first 100 patients diagnosed with COVID-19 at our institution, associated with advanced age and the presence of serious underlying diseases.

Keywords: SARS-CoV-2, COVID-19, Coronavirus

\section{Los primeros 100 casos de COVID-19 en un Hospital de Madrid con seguimiento de 2 meses}

\section{RESUMEN}

Antecedentes. Existen pocas descripciones de la presentación clínica y evolución de infecciones consecutivas por SARS-CoV-2 con un seguimiento lo suficientemente largo.

Métodos. Descripción de los primeros 100 pacientes consecutivos con COVID-19 probada microbiológicamente en un gran hospital de Madrid, incluyendo un seguimiento mínimo de dos meses.

Resultados. La mediana de edad de los pacientes (52\% hombres) fue de 61,5 años ( $\mathrm{RIC}=39,5-82,0)$ y la mediana de IMC fue de $28,8 \mathrm{~kg} / \mathrm{m}^{2}$ (RIC $\left.=24,7-33,7\right)$. El $72 \%$ de los pacientes tuvieron una o más comorbilidades con un índice de Charlson ajustado a la edad de $2(\mathrm{RIC}=0-5,7)$. Cinco pacientes $(5 \%)$ estaban inmunodeprimidos. Los sintomas más comunes al momento del diagnóstico fueron fiebre $(80,0 \%)$, tos $(53,0 \%)$ y disnea $(23,0 \%)$. La mediana de saturación de $\mathrm{O}_{2}$ en el momento del primer examen fue del $94 \%(\mathrm{RIC}=90-97)$. La radiografía de tórax al ingreso fue compatible con neumonía en el $63 \%$ de los casos (bilateral en el $42 \%$ y unilateral en el $21 \%$ ). El 30\% fueron manejados en su domicilio y el 70\% ingresados en el hospital. Trece pacientes ingresaron en la $\mathrm{UCl}$ con una mediana de 11 dias de estancia en la Unidad ( $R I C=6,0-28,0)$. 
El score CALL de nuestra población varió de 4 a 13. En general, el $60,0 \%$ de los pacientes recibió tratamiento antibiótico y el $66,0 \%$, tratamiento antiviral empirico, principalmente con lopinavir/ritonavir (65\%) o hidroxicloroquina (42\%). La mortalidad, con un mínimo de 60 dias de seguimiento, fue del $23 \%$. La mediana de edad de los pacientes fallecidos fue de 85 años ( $\mathrm{RIC}=79-93)$.

Conclusiones. Encontramos una alta mortalidad en los primeros 100 pacientes diagnosticados con COVID-19 en nuestra institución, asociada con edad avanzada y presencia de enfermedades subyacentes graves.

Palabras clave: SARS-CoV-2, COVID-19, Coronavirus

\section{INTRODUCTION}

The COVID-19 epidemic is yielding highly variable data on incidence, evolution and mortality from one report to another, largely because the populations described are not comparable. On the other hand, the rush to provide valid scientific information on the epidemic means that many reports are preliminary and do not offer a sufficiently comprehensive perspective on the evolution of patients [1-10].

The first case of COVID-19 was confirmed in the Community of Madrid on February 27th, 2020 in a 24-year-old patient who had recently travelled to northern Italy. On March 1st, 2020, our institution (Hospital General Universitario Gregorio Marañón - HGUGM) admitted the first confirmed case to the Center and within 10 days another 99 patients were diagnosed consecutively. During this period, the diagnosis of SARS-CoV-2 infection was offered exclusively to symptomatic patients.

The criteria for hospital admission was initially systematic but soon those who did not have severity criteria began to be treated at home.

Having these first 100 patients a follow-up of 60 , or more days in all cases, our objective is to evaluate this first series, with a special perspective on its presentation, treatment, evolution, and mortality.

\section{MATERIAL AND METHODS}

Location of the study. The Hospital General Universitario Gregorio Marañón is a general and reference hospital, linked to the Universidad Complutense, with 1,350 beds, serving a population of approximately 350,000 inhabitants in the southeast area of Madrid. The Centre performs highly complex surgery, attends to patients with malignant diseases of both solid and haematological organs, has a very active transplant programme and is a reference center for many diseases. The Clinical Microbiology and Infectious Diseases Service is a multidisciplinary unit with a long history of care, teaching and research.

Type of study and population. This is a single-centre retrospective observational study that includes the first 100 consecutive patients with a proven diagnosis of COVID-19 in the HGUGM since the beginning of the epidemic, with a minimum follow-up of 60 days after etiological confirmation.

Procedures. The diagnosis of COVID-19 was performed in all cases from nasopharyngeal samples by reverse transcriptase polymerase chain reaction (Roche/Thermo Fisher RT-PCR) with prior extraction of viral RNA by NucliSENS ${ }^{\circledR}$ easyMag ${ }^{\circledR}$ (bioMérieux). A cycle threshold value (Ct-value) of less than 37 was considered positive. PCR (Roche/Thermo Fisher RT-PCR) from nasopharyngeal exudate was performed from the virus medium in which the samples are transported. The rest of the analytical determinations in blood followed the conventional methods established in our hospital.

Data collected. The following data were collected for each patient: demographic characteristics, underlying conditions, previous contact with suspected cases, days with symptoms prior to diagnosis by PCR, hospital stay, ICU stay, presence of pneumonia (unilateral/bilateral), oxygen saturation, laboratory analysis, severity of infection, antibiotic, antifungal and antiviral therapy, clinical evolution and mortality.

Definitions. Immunosuppressed patients were considered to be those with active solid organ tumor, malignant/hematological neoplasms under chemotherapy, HIV patients $(<200$ CD4), neutropenic individuals $\left(<500 \mathrm{~mm}^{3}\right)$, solid organ transplant recipients or those under corticosteroid therapy at doses equivalent to $\geq 15 \mathrm{mg}$ of prednisone (or equivalent)/day in the 30 days prior to admission.

Proven infection by SARS-CoV-2 was considered when a patient had signs and symptoms compatible with COVID-19 and a positive PCR in nasopharyngeal exudate.

The severity of the patients' disease was classified by the "CALL (comorbidity, age, lymphocyte and LDH) score" [11], which ranks 3 levels of risk according to their probability of progression. Those patients with 4-6 points have less than $10 \%$ chance of progression and are considered low risk (Class A). Patients with 7-9 points had a 10-40\% chance of progression and are at intermediate risk (Class B) and patients with 10-13 points with more than 50\% chance of progression are considered at high risk (Class $\mathrm{C}$ ).

Statistical analysis. The median and interquartile range, were used for descriptive analysis of continuous variables. A value of $p<0.05$ was considered significant. Categorical variables were compared with the chi-square test and continuous variables using the Mann-Whitney test. A multivariate forward analysis including variables with $p<0.01$ in the univariate analysis was carried out to identify mortality risk factors. Statistical analysis was performed using IBM SPSS Statistics v.21 (IBM Corp., Armonk, NY).

Ethical aspects. This study was approved by the HGUGM Ethics Committee with the code MICRO.HGUGM.2020-020.

\section{RESULTS}

Of the first 100 proven patients with COVID-19 at the HGUGM, 52\% were male. The age of the patients ranged from 


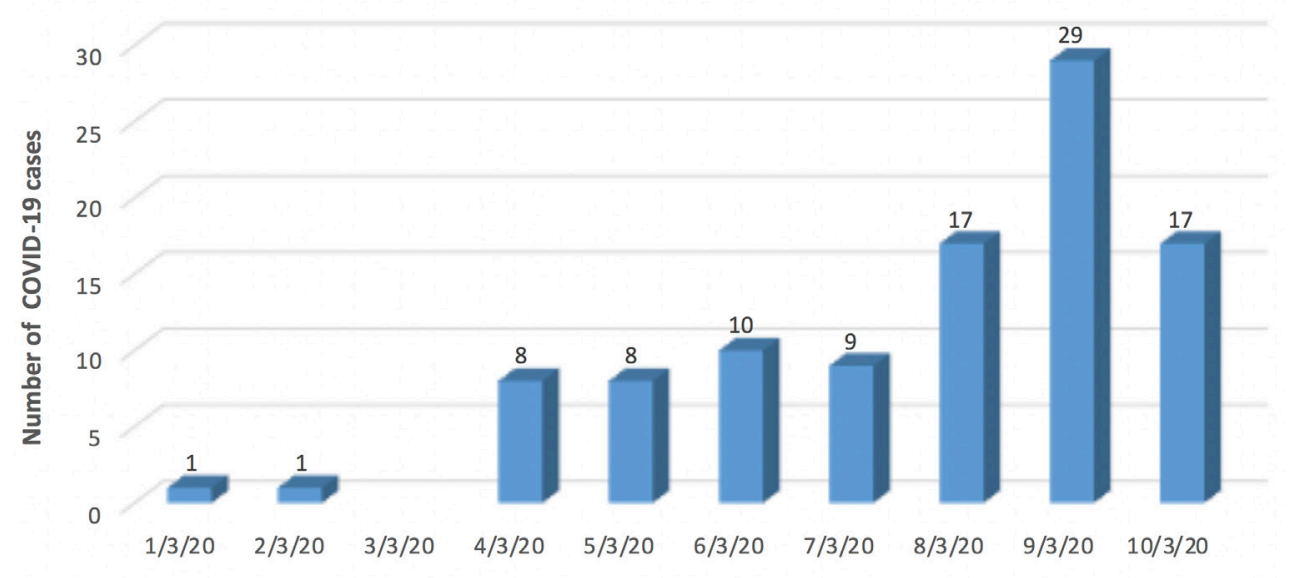

Date of COVID-19 diagnosis

Figure 1 Evolution of admissions of the first 100 cases with confirmed COVID-19 at Hospital General Universitario Gregorio Marañón.

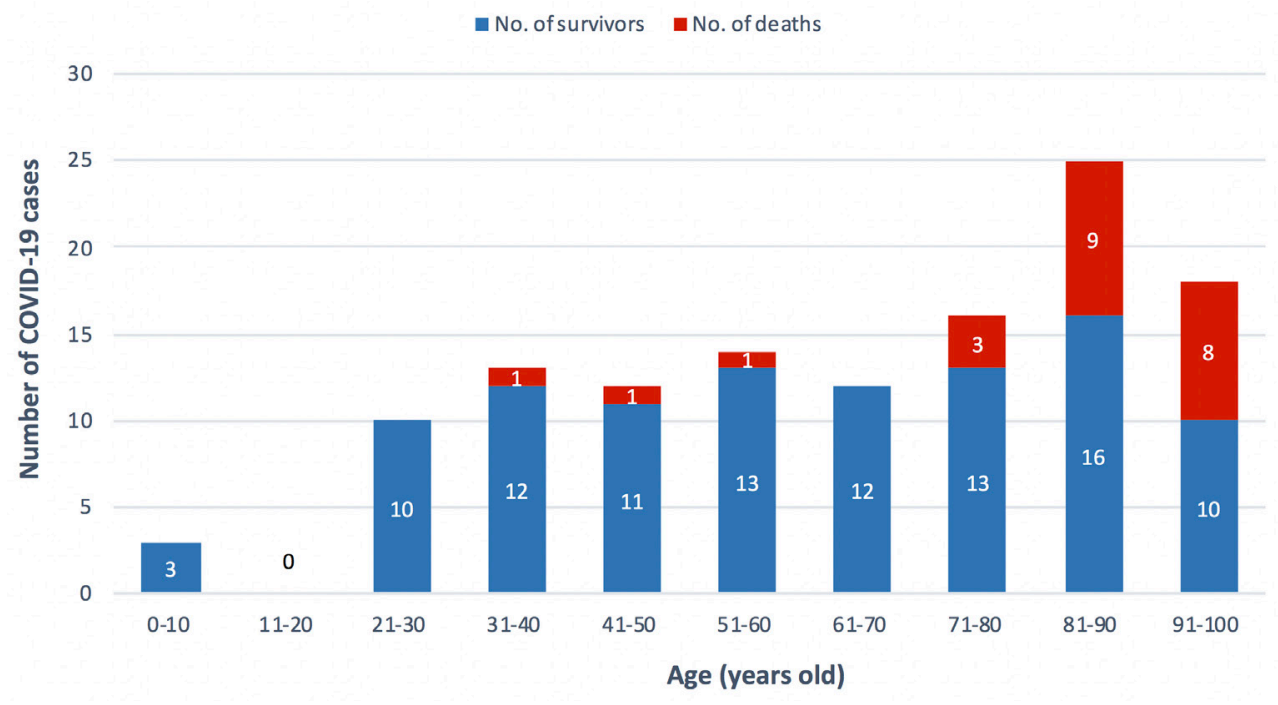

\begin{tabular}{l|l} 
Figure 2 & $\begin{array}{l}\text { Distribution of the first 100 COVID-19 cases (survivors/deaths) in the } \\
\text { Hospital General Universitario Gregorio Marañón by decades of life. }\end{array}$
\end{tabular}

3 months to 99 years with a median of 61.5 years (IQR $=39.5-$ 82.0). Figure 1 shows the speed at which the first 100 cases of COVID-19 were diagnosed in our institution and Figure 2 shows their distribution by decades of life and mortality rate.

The median patient weight was $75.8 \mathrm{~kg}$ (IQR=64.785.0 ) and the median Body Mass Index (BMI) was $28.8 \mathrm{~kg} / \mathrm{m}^{2}$ $\left(I O R=24.7-33.7 \mathrm{~kg} / \mathrm{m}^{2}\right)$. The characteristics of the patients and the main underlying diseases are shown in Table 1.

The most common comorbidities were hypertension $(31 \%)$, heart disease $(22 \%)$ and diabetes mellitus (19\%). The age-adjusted Charlson index [12] ranged from a minimum of 0 to a maximum of 10 (median 2, IQR=0-5.7). Five patients (5\%) were immunosuppressed. Twenty-eight percent of the patients had no underlying disease.

The most common symptoms presented by patients at the time of diagnosis were fever (80.0\%), cough (53.0\%) and dyspnea (23.0\%), followed by myalgia (7.0\%), chest discomfort $(5.0 \%)$ and asthenia (4.0\%) (Table 1). The median number of days patients referred symptoms prior to performing the diagnostic PCR of COVID-19 was 4.0 (IQR= 2.0-7.0) with a mini- 


\section{\begin{tabular}{l|l} 
Table 1 & Demographic, clinical characteristics
\end{tabular} and evolution of patients.}

\begin{tabular}{|c|c|}
\hline & Cases $(n=100)$ \\
\hline Age, median, IQR & $61.5(39.5-82.0)$ \\
\hline Sex, male, n (\%) & $52(52.0)$ \\
\hline $\mathrm{BMI}, \mathrm{kg} / \mathrm{m} 2$ & $28.8(24.7-33.7)$ \\
\hline \multicolumn{2}{|l|}{ Underlying diseases, $n(\%)$} \\
\hline Cardiopathy & $22(22.0)$ \\
\hline Diabetes mellitus & $19(19.0)$ \\
\hline Malignant/Hematological neoplasia & $11(11.0)$ \\
\hline Chronic obstructive pulmonary disease & $10(10.0)$ \\
\hline Chronic renal disease & $8(8.0)$ \\
\hline Chronic hepatic disease & $7(7.0)$ \\
\hline Neurologic disease & $6(6.0)$ \\
\hline Solid tumor & $6(6.0)$ \\
\hline Psychiatric disease & $1(1.0)$ \\
\hline Hemodialysis & 0 \\
\hline HIV & 0 \\
\hline Solid organ trasplantation & 0 \\
\hline \multicolumn{2}{|l|}{ Other } \\
\hline Hypertension & $31(31.0)$ \\
\hline Hypothyroidism & $8(8.0)$ \\
\hline Asthma & $4(4.0)$ \\
\hline Cushing illness & $1(1.0)$ \\
\hline Celiac disease & $1(1.0)$ \\
\hline Lupus & $1(1.0)$ \\
\hline Sarcoidosis & $1(1.0)$ \\
\hline Myopathy & $1(1.0)$ \\
\hline Crohn disease & $1(1.0)$ \\
\hline Peptic esophagitis & $1(1.0)$ \\
\hline Osteoporosis & $1(1.0)$ \\
\hline Thyroiditis de Hashimoto & $1(1.0)$ \\
\hline Colon angiodysplasia & $1(1.0)$ \\
\hline Latent tuberculosis & $1(1.0)$ \\
\hline None, n $(\%)$ & $28(28.0)$ \\
\hline Inmunodepressed, $n(\%)$ & $5(5.0)$ \\
\hline Charlson Index adjusted to age, median, IOR & $2(0-5.7)$ \\
\hline Previous contact, $n(\%)$ & $47(47.0)$ \\
\hline Days with symptoms previous to PCR, median, IQR & $4.0(2.0-7.0)$ \\
\hline \multicolumn{2}{|l|}{ Symptoms, n, \% } \\
\hline Fever & $80(80.0)$ \\
\hline Cough & $53(53.0)$ \\
\hline Dyspnoea & $23(23.0)$ \\
\hline Myalgia & $7(7.0)$ \\
\hline Thoracic pain & $5(5.0)$ \\
\hline Asthenia & $4(4.0)$ \\
\hline
\end{tabular}

Table 1 Demographic, clinical characteristics and evolution of patients (cont.)

\begin{tabular}{|c|c|}
\hline & Cases $(n=100)$ \\
\hline Headache & $3(3.0)$ \\
\hline Confusional syndrome & $3(3.0)$ \\
\hline Vomiting & $3(3.0)$ \\
\hline Diarrhea & $3(3.0)$ \\
\hline Dizziness & $2(2.0)$ \\
\hline Odinofagia & $2(2.0)$ \\
\hline Rhinorrea & $1(1.0)$ \\
\hline Conjunctivitis & $1(1.0)$ \\
\hline Pleuritic pain & $1(1.0)$ \\
\hline Syncope & $1(1.0)$ \\
\hline Need of hospitalization, n (\%) & $70(70.0)$ \\
\hline Days of hospital stay, median, IOR & $9.0(7.0-15.2)$ \\
\hline Need of ICU hospitalization, n (\%) & $13(13.0)$ \\
\hline Days of ICU stay, median, IQR & $11.0(6.0-28.0)$ \\
\hline Pneumonia, n (\%) & $63(63.0)$ \\
\hline Unilateral pneumonia & $21(21.0)$ \\
\hline Bilateral pneumonia & $42(42.0)$ \\
\hline $\begin{array}{l}\text { Oxygen saturation at hospital admission, median, } \\
\text { IQR }\end{array}$ & $94.0(90.0-97.0)$ \\
\hline $\begin{array}{l}\text { Lower level of oxygen saturation during } \\
\text { hospitalization, median, IOR }\end{array}$ & $92.0(88.0-94.0)$ \\
\hline Antiviral treatment, $\mathrm{n}(\%)$ & $66(66.0)$ \\
\hline Antibiotic treatment, $n(\%)$ & $60(60.0)$ \\
\hline Antifungal treatment, $\mathrm{n}(\%)$ & $5(5.0)$ \\
\hline Clinical outcome at 30 days, alive, n (\%) & $77(77.0)$ \\
\hline Recovered at home & $72(72.0)$ \\
\hline Hospitalized & $2(2.0)$ \\
\hline At ICU & $3(3.0)$ \\
\hline Clinical outcome at 60 days, alive, $n(\%)$ & $77(77.0)$ \\
\hline Recovered at home & $75(75.0)$ \\
\hline Hospitalized & $11.0)$ \\
\hline At ICU & $2(2.0)$ \\
\hline Mortality & $23(23.0)$ \\
\hline Related to COVID & $22(22.0)$ \\
\hline Not related to COVID & $1(1.0)$ \\
\hline \multicolumn{2}{|l|}{ Complications } \\
\hline Cardiopathy & $18(18.0)$ \\
\hline Acute respiratory distress syndrome & $30(30.0)$ \\
\hline Sepsis syndrome & $17(17.0)$ \\
\hline Proven bacterial sepsis & $9(9.0)$ \\
\hline Acute kidney injury & $27(27.0)$ \\
\hline Acute liver injury & $25(25.0)$ \\
\hline Pulmonary embolism & $1(1.0)$ \\
\hline
\end{tabular}




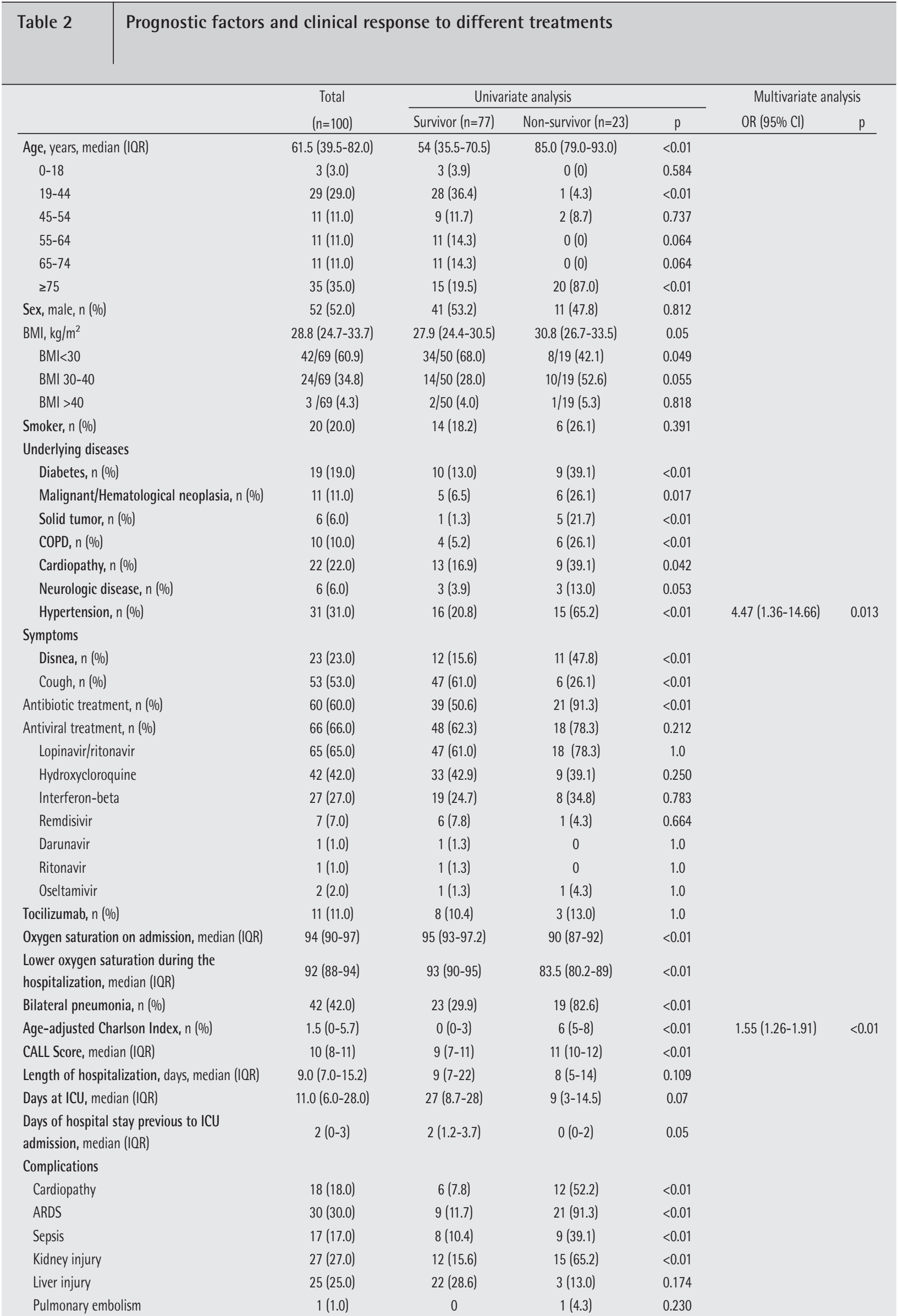

COPD: chronic obstructive pulmonary disease, ARDS: acute respiratory distress syndrome 


\begin{tabular}{|c|c|c|c|c|c|}
\hline \multirow{2}{*}{\multicolumn{2}{|c|}{ Summary of mair }} & \multicolumn{4}{|c|}{ Summary of main laboratory results. } \\
\hline & & $\begin{array}{c}\text { Total } \\
(n=100)\end{array}$ & $\begin{array}{l}\text { Survivor } \\
(n=77)\end{array}$ & $\begin{array}{l}\text { Non-survivor } \\
\qquad(\mathrm{n}=23)\end{array}$ & p \\
\hline \multicolumn{2}{|c|}{ Lymphocyte count $(10 \mathrm{E} 3 / \mu \mathrm{L})$, median, IQR } & $0.9(0.7-1.3)$ & $1(0.7-1.4)$ & $0.7(0.5-1.1)$ & $<0.01$ \\
\hline \multicolumn{2}{|l|}{$<1.3$} & $55 / 77(71.4 \%)$ & $36 / 55(65.5)$ & $19 / 22(86.4)$ & 0.094 \\
\hline \multicolumn{2}{|l|}{$<0.8$} & $31 / 77(40.3 \%)$ & $18 / 55(32.7)$ & 13/22 (59.1) & 0.042 \\
\hline \multicolumn{2}{|c|}{ Platelets $(10 \mathrm{E} 3 / \mu \mathrm{L})$, median, IQR } & $155(136-205.2)$ & $159(136-239.5)$ & $155(100-188)$ & 0.189 \\
\hline \multicolumn{2}{|l|}{$<140$} & $24 / 78(30.8 \%)$ & $15 / 56(26.8)$ & $9 / 22(40.9)$ & 0.278 \\
\hline \multicolumn{2}{|l|}{$\geq 140$} & $54 / 78(69.2 \%)$ & $41 / 56(73.2)$ & $13 / 22(59.1)$ & \\
\hline \multicolumn{2}{|c|}{ C-reactive protein (mg/dL), median, IOR } & $4(2-9.6)$ & $2.7(1.5-6.5)$ & $6.3(3.3-17.6)$ & $<0.01$ \\
\hline \multicolumn{2}{|c|}{ Procalcitonin $(\mu \mathrm{g} / \mathrm{L})$, median, IOR } & $0.05(0.03-0.13)$ & $0.04(0.03-0.08)$ & $0.12(0.1-0.5)$ & $<0.01$ \\
\hline \multicolumn{2}{|l|}{$<0.1$} & $53 / 79(67.1 \%)$ & $44 / 56(78.6)$ & $9 / 23(39.1)$ & $<0.01$ \\
\hline \multicolumn{2}{|c|}{$\geq 0.1 \mathrm{a}<0.25$} & $12 / 79(15.2 \%)$ & $5 / 56(8.9)$ & $7 / 23(30.4)$ & 0.022 \\
\hline \multicolumn{2}{|c|}{$\geq 0.25 \mathrm{a}<0.5$} & $6 / 79(7.6 \%)$ & $4 / 56(7.1)$ & $2 / 23(8.7)$ & 1.0 \\
\hline \multicolumn{2}{|l|}{$\geq 0.5$} & $8 / 79(10.1 \%)$ & $3 / 56(5.4)$ & $5 / 23(21.7)$ & 0.042 \\
\hline \multicolumn{2}{|c|}{ D-dimer (ng/mL), median, IQR } & $284(219-794)$ & $274(208-680.5)$ & 2010 (565-) & 0.154 \\
\hline \multicolumn{2}{|c|}{ ALT (U/L), median, IOR } & $24(15-37)$ & $24.5(15-38.7)$ & $24(17-34)$ & 0.754 \\
\hline \multicolumn{2}{|l|}{$\leq 41$} & $64 / 79(81.0 \%)$ & $44 / 56(78.6)$ & $20 / 23(87.0)$ & 0.533 \\
\hline \multicolumn{2}{|l|}{$>41$} & $15 / 79(19.0 \%)$ & $12 / 56(21.4)$ & $3 / 23(13.0)$ & \\
\hline \multicolumn{2}{|c|}{ LDH (U/L), median, IQR } & $256(192.5-345.7)$ & $226(191-297)$ & $316(224-434)$ & 0.047 \\
\hline \multicolumn{2}{|l|}{$\leq 250$} & $32 / 66(48.5 \%)$ & $28 / 49(57.1)$ & $4 / 17(23.5)$ & 0.024 \\
\hline \multicolumn{2}{|l|}{$250-500$} & $28 / 66(42.4 \%)$ & $17 / 49(34.7)$ & $11 / 17(64.7)$ & 0.046 \\
\hline \multicolumn{2}{|l|}{$>500$} & $6 / 66(9.1 \%)$ & $4 / 49(8.2)$ & 2/17 (11.8) & 1.0 \\
\hline \multicolumn{2}{|c|}{ IL-6 (pg/mL), median, IQR } & 166.3 (61.4-) & 166.3 (61.4-) & - & - \\
\hline \multicolumn{2}{|c|}{ Blood urea nitrogen, $(\mathrm{mg} / \mathrm{dL})$, median, $10 R$} & $31(19-79)$ & $21(17-31)$ & $106(61.7-205.7)$ & $<0.01$ \\
\hline \multicolumn{2}{|c|}{ Ferritin $(\mu \mathrm{g} / \mathrm{L})$, median, IQR } & $598(267-1048.5)$ & $494(153-681)$ & 2922 (676-) & 0.222 \\
\hline \multicolumn{2}{|c|}{ NTproBNP (ng/L), median, IQR } & 1036 (274-3981) & 465 (74-2500.5) & $1520.5(588.2-5900)$ & 0.012 \\
\hline
\end{tabular}

mum of 1 day and a maximum of 14 days. Forty-seven percent of the patients stated that they had had previous contact with a person diagnosed with COVID-19, either proven or probable.

$\mathrm{O}_{2}$ saturation at the time of first examination ranged from a minimum of $80 \%$ to a maximum of $99 \%$, with a median of $94 \%(I O R=90-97)$. A total of $19.8 \%$ of patients had saturation $<90 \%$ on admission.

Sixty-three percent of the patients presented alterations in the chest X-Ray on admission, compatible with the diagnosis of pneumonia (Table 1). Radiological images were classified as bilateral pneumonia in $42 \%$ of patients and as unilateral in $21 \%$. The infiltrates generally had a ground glass pattern but on some occasions they were clear alveolar infiltrates (Figure 3).

Overall, 70\% of COVID-19 cases were admitted to hospital. The length of hospital stay for those patients who remained hospitalized ranged from a minimum of 1 day to a maximum of 32 days, with a median of 9 days $(I O R=7.0-15.2)$. Thirteen patients required admission to the ICU during the course of their hospitalization, with a minimum of 2 days and a maximum of 28 days of stay and a median of 11 days (IOR=6.028.0). The mortality rate of these patients admitted to ICU was $38.5 \%$ (5/13). The median time from the onset of symptoms associated with COVID-19 in these patients until they were admitted to the ICU was 5 days $(I O R=1.5-9.5)$ with a minimum of 1 day and a maximum of 13 days. Patients admitted to the ICU were previously hospitalized on the ward for a median of 2 days $(I Q R=0-3)$ with a minimum of 0 days and a maximum of 6 days.

Fourteen patients of our study cohort also showed other type of infections $(n=17)$. Three of them were coinfections present at the same time as the diagnosis of SARS-CoV-2 and 14 were nosocomially acquired. The origin of all of them was 


\begin{tabular}{|c|c|c|c|c|}
\hline \multirow{2}{*}{\multicolumn{2}{|c|}{ Comparative study }} & terms of severity $\mathrm{s}$ & e (CALL score) & \multirow[b]{2}{*}{$p$} \\
\hline & & $\begin{array}{c}\text { Class } A \text { and } B \\
\text { (low and intermediate risk) } \\
n=29\end{array}$ & $\begin{array}{c}\text { Class } C \\
\text { (high risk) } \\
n=37\end{array}$ & \\
\hline Age, media & & $51(34.5-71)$ & $76(64-86)$ & $<0.01$ \\
\hline Charlson Ir & nedian, IOR & $0(0-5)$ & $4(2-6.5)$ & $<0.01$ \\
\hline 0xygen sat & $\mathrm{n}$ on admission, median, IQR & $95(94-97)$ & $92(88-95)$ & $<0.01$ \\
\hline Dyspnoea, & & $4 / 29(13.8 \%)$ & $15 / 37(40.5 \%)$ & 0.027 \\
\hline Antibiotic & ent, $n, \%$ & $19 / 29(65.5 \%)$ & $33 / 37(89.2 \%)$ & 0.032 \\
\hline \multicolumn{5}{|c|}{ Complications } \\
\hline Cardiop & $1, \%$ & $2 / 29(6.9 \%)$ & $3 / 37(35.1 \%)$ & $<0.01$ \\
\hline ARDS, $n$ & & $6 / 29(20.7 \%)$ & $18 / 37(48.6 \%)$ & 0.023 \\
\hline Kidney & $n, \%$ & $5 / 29(17.2 \%)$ & $28 / 37(48.6 \%)$ & 0.01 \\
\hline Survivor at & ay follow-up (at home), n, \% & $26 / 29(89.7 \%)$ & $18 / 37(48.6 \%)$ & $<0.01$ \\
\hline \multicolumn{5}{|l|}{ Laboratory } \\
\hline Lympho & ount, median, IOR & $1.3(1.1-1.5)$ & $0.7(0.4-0.9)$ & $<0.01$ \\
\hline C-react & tein, median, IOR & $2.3(1.3-4.7)$ & $5.3(2.8-11.8)$ & $<0.01$ \\
\hline Procalci & median, IQR & $0.04(0.03-0.06)$ & $0.09(0.04-0.3)$ & $<0.01$ \\
\hline LDH, me & & $212(190.5-267.5)$ & $283(211.5-399.5)$ & $<0.01$ \\
\hline
\end{tabular}

ARDS: acute respiratory distress syndrome

urinary $(n=6)$, respiratory $(n=5)$, bloodstream $(n=4,2$ primary bacteremia and 2 catheter-related bacteremia), gastrointestinal $(n=1)$ and catheter-related $(n=1)$ infections. The most frequently isolated microorganisms were Escherichia coli $(n=5)$, Staphylococcus epidermidis $(n=2)$, Staphylococcus aureus $(n=1)$, Enterobacter cloacae $(n=1)$, Klebsiella pneumoniae $(n=1)$, Micrococcus luteus $(n=1)$, Enterococcus faecalis $(n=1)$, Staphylococcus haemolyticus $(n=1)$, Aspergillus fumigatus complex $(n=1)$, Respiratory Syncytial Virus $(n=1)$ and Clostridium difficile $(n=1)$. Nine cases of proven bacterial sepsis were detected among 17 patients with sepsis syndrome.

Overall, $60.0 \%$ of patients received antibiotic treatment and $66.0 \%$ of patients received antiviral treatment, with lopinavir/ritonavir (65\%) or hydroxychloroquine (42\%) in an empirical basis. The main treatments are shown in Table 2. A greater use of antibiotics was observed in patients who died compared to survivors ( $91.3 \%$ vs $50.6 \%, p<0.01)$ but no significant differences were detected between both groups in terms of any type of antiviral or monoclonal antibody administered as treatment to the COVID-19.

Laboratory findings showed lymphopenia in 71\% of patients diagnosed with COVID-19 with analytical determination on admission. Fourteen of the 23 patients with D-dimer determination (60.9\%), had values greater than $250 \mathrm{ng} / \mathrm{mL}$. IL-6 was only measured in 3 patients of our cohort but values were elevated in all the cases. Lymphocyte levels were lower in patients who died $(p<0.01)$ compared to those who survived. C-reactive protein, procalcitonin, LDH, blood nitrogen-urea and NTproB$\mathrm{NP}$ values were significantly higher in non-survivors compared to survivors at 30-60 days after diagnosis of COVID-19 (Table 3).

The median CALL score of the total patient cohort was 10, corresponding to Class $\mathrm{C}$ severity with a probability of more than $50 \%$ high risk of disease progression. The minimum CALL score was 4 (Class A) and the maximum was 13 (Class C) (Table $2)$. A significantly higher CALL score $(p<0.01)$ was observed in patients who died compared to those who did not die (11 vs 9). When comparing patients with low-intermediate severity (Class A and B CALL score) with patients with high severity (Class C, CALL score), it was observed that those with greater probability of disease progression (Class $\mathrm{C}$ ) presented greater age $(p<0.01)$, higher Charlson index $(p<0.01)$, more dyspnea (40.5\% vs $13.8 \%, p<0.01)$, higher percentage of antibiotic use $(89.2 \%$ vs $65.5 \%, p<0.05)$ and a greater presence of complications such as heart disease $(p<0.04)$, respiratory distress $(p<0.05)$ and kidney damage $(p=0.01)$ (Table 4$)$. The percentage of survivors was lower in this group (48.6\% goes $89.7 \%$, $\mathrm{p}<0.01)$. Regarding laboratory findings, lymphocyte, $\mathrm{C}$-reactive protein, procalcitonin and LDH levels were significantly higher in these high severity patients $(p<0.01)$.

At 30 days of follow-up after positive PCR test for SARSCoV-2, 23 patients (23\%) had died, 72 (72\%) were recovering 
at home, $2(2 \%)$ remained hospitalized and $3(3 \%)$ were in the ICU. After 60 days of follow-up, no more deaths were detected in our cohort, one of the 2 patients who had been hospitalized at 30 days remained hospitalized and the other was at home. As for the ICU patients, 2 remained hospitalized at 60 days and the third was discharged after 49 days of admission. Figure 2 shows the distribution of patients who survived and died by age groups (decades).

A comparative study between live and dead patients 3060 days after diagnosis of COVID-19 showed that dead patients were significantly older $(p<0.01)$, had a higher Charlson index $(p<0.01)$ and had a higher percentage of bilateral pneumonias $(p<0.01)$. The frequency of complications was higher in non-survivors than in survivors. Table 2 shows this comparison and the profile of the deceased patients in detail. By performing a multivariate analysis including variables with statistical significance in the univariate analysis less than 0.01 , the presence of hypertension and age-adjusted Charlson Index were identified as risk factors associated with death.

The age of the deceased patients ranged from 39 to 99 years with a median of 85 years (IQR=79-93). Only 3 of the 23 deceased patients (13\%) were under 75 years of age. One of them (51 years old) had diabetes mellitus, Cushing's disease, high blood pressure, hepatitis $\mathrm{C}$ and SARS-CoV-2 coinfection with RSV. Another (45 years old) had diabetes mellitus, high blood pressure, morbid obesity, chronic renal disease, Clostridium difficile colitis and was a carrier of a biological mitral prosthesis. The third, was a 39 years old patient with epidermoid carcinoma of the cervix treated with surgery in 2014 and currently with stage IV anal canal carcinoma in progression, with peritoneal carcinomatosis in treatment with palliative chemotherapy. The 23 patients who died had a median Charlson Index of $6(I Q R=5-8)$. Eleven patients $(47.8 \%)$ had a BMI greater than 30 and 3 were immunosuppressed. Nineteen patients (82.6\%) had bilateral pneumonia and $4(17.4 \%)$ had unilateral pneumonia.

\section{DISCUSSION}

Our study shows a high mortality of the first hundred patients treated with COVID-19 in our institution, associated with advanced age and the presence of serious underlying diseases in our population. Twenty of the $23(23 \%)$ deceased patients were over 75 years of age and all had serious comorbidities.

The mortality in our series is similar to that reflected by Western countries such as Italy, UK, USA and others (19\% to $39 \%)[3,13-15]$ and differs significantly from that reported from China or Korea $(0.9 \%$ to $7.5 \%)[4,16-20]$. It is clear that when calculating mortality the denominators matter $[17,21$, 22].

The basic reason for these differences are to be found in the median age of the respective populations which was between 62 and 65.5 years in Western publications $[3,13,15]$ and between 41 and 47 in the case of Chinese publications [4,
18]. In addition, comorbidity appears as a clear factor of poor prognosis as well as the level of care $[23,24]$.

Mortality in the case of China is even more surprising, since the initially reported cases considered pneumonia as a constant in clinical presentation $[2,25-28]$, to the extent that the presence of certain lesions in the thoracic CT was considered a diagnostic criterion in the early stages [29-31]. However, as demonstrated by our first 100 microbiologically confirmed patients, pneumonia was absent in a high proportion of cases and is even less frequent in subsequent series where diagnostic suspicion is spread to less severe or asymptomatic patients $[4,19,32]$.

An interesting aspect of our series is the evaluation of the ability to predict and anticipate patients with poor clinical evolution. Our study has used the CALL score [11] and validated its usefulness. For example, all the patients sent home, evolved well during the follow-up and did not require admission in the two months of follow-up.

No antiviral treatment has been shown to be effective to date. Most patients in our cohort were treated with lopinavir/ ritonavir but none of the different types of antivirals administered during this first period have shown significant differences between patients who survived and those who died [33-39].

Our results and previous studies show that lymphopenia is common in COVID-19 cases, suggesting that SARS-CoV-2 infection causes an inhibition of the cellular immune response and a significant number of complications as seen in our patient cohort. We have also observed that elevation of markers such as $\mathrm{C}$-reactive protein and procalcitonin is common in severe COVID-19 cases $[4,40]$.

Our study aims to contribute to a better understanding of the clinical evolution and mortality among the cases of COVID-19 in different continents, with a follow-up perspective of more than two months. The real mortality will not be known until the true dimension of the epidemic can be analyzed through population studies and the number of deceased cases can be related to the underlying diseases and the situation of the hospitals at different times of the epidemic.

\section{ACKNOWLEDGEMENTS}

Gregorio Marañón Microbiology-ID COVID 19 Study Group:

Alcalá (Luis), Aldámiz (Teresa), Alonso (Roberto), Álvarez (Beatriz), Álvarez-Uría (Ana), Andueza (Juan Antonio), Arias (Alexi), Arroyo (Luis Antonio), Berenguer (Juan), Bermúdez (Elena), Bouza (Emilio), Burillo (Almudena), Candela (Ana), Carrillo (Raquel), Catalán (Pilar), Cercenado (Emilia), Cobos (Alejandro), Diez (Cristina), Escribano (Pilar), Estévez (Agustín), Fanciulli (Chiara), Galar (Alicia), Garcia (Ma Dolores), Garcia de Viedma (Darí), Gijón (Paloma), González (Adolfo), Guerrero (José Eugenio), Guillén (Helmuth) Guinea (Jesús), Haces (Laura Vanessa), Kestler (Martha), López (Juan Carlos), Losada (Carmen Narcisa), Machado (Marina), Marín (Mercedes), Martín (Pab- 
Io), Montilla (Pedro), Moure (Zaira), Muñoz (Patricia), Olmedo (Maria), Padilla (Belén), Palomo (María), Parras (Francisco), Pérez-Granda (María Jesús), Pérez (Laura), Pérez (Leire), Pescador (Paula), Puente (Luis), Reigadas (Elena), Rincón (Cristina), Rodríguez (Belén), Rodríguez (Sara), Rojas (Adriana), Ruiz-Serrano (María Jesús), Sánchez (Carlos), Sánchez (Mar), Serrano (Julia), Tejerina (Francisco), Valerio (Maricela), Veintimilla ( ${ }^{a}$ Cristina), Vesperinas (Lara), Vicente (Teresa), de la Villa (Sofia).

\section{FUNDING}

This study was supported by internal funding. Alicia Galar and Teresa Aldamiz-Echevarría are supported by Juan Rodés contracts from the Instituto de Salud Carlos III, Madrid, Spain, partially financed by the European Social Fund (grant numbers JR18/00030 and JR17/00018, respectively).

\section{CONFLICT OF INTEREST}

The authors declare that they have no conflicts of interest

\section{REFERENCES}

1. Arons MM, Hatfield KM, Reddy SC, Kimball A, James A, Jacobs JR, et al. Presymptomatic SARS-CoV-2 Infections and Transmission in a Skilled Nursing Facility. N Engl J Med. 2020;382(22):2081-90. DOI: 10.1056/NEJMoa2008457

2. Chen N, Zhou M, Dong $X, \mathrm{Qu}$ J, Gong $F$, Han Y, et al. Epidemiological and clinical characteristics of 99 cases of 2019 novel coronavirus pneumonia in Wuhan, China: a descriptive study. Lancet. 2020;395(10223):507-13. DOI: 10.1016/S0140-6736(20)30211-7

3. Grasselli G, Zangrillo A, Zanella A, Antonelli M, Cabrini L, Castelli A, et al. Baseline Characteristics and Outcomes of 1591 Patients Infected With SARS-CoV-2 Admitted to ICUs of the Lombardy Region, Italy. JAMA. 2020;323(16):1574-1581. DOI: 10.1001/jama.2020.5394

4. Guan WJ, Ni ZY, Hu Y, Liang WH, Ou CQ, He JX, et al. Clinical Characteristics of Coronavirus Disease 2019 in China. N Engl J Med. 2020;382(18):1708-1720. DOI: 10.1056/NEJMoa2002032

5. Latif F, Farr MA, Clerkin KJ, Habal MV, Takeda K, Naka Y, et al. Characteristics and Outcomes of Recipients of Heart Transplant With Coronavirus Disease 2019. JAMA Cardiol. 2020. DOI: 10.1001/jamacardio.2020.2159

6. Richardson $\mathrm{S}$, Hirsch JS, Narasimhan M, Crawford JM, McGinn T, Davidson KW, et al. Presenting Characteristics, Comorbidities, and Outcomes Among 5700 Patients Hospitalized With COVID-19 in the New York City Area. JAMA. 2020;323(20):2052-2059. DOI: 10.1001/jama.2020.6775

7. Wang D, Hu B, Hu C, Zhu F, Liu X, Zhang J, et al. Clinical Characteristics of 138 Hospitalized Patients With 2019 Novel Coronavirus-Infected Pneumonia in Wuhan, China. JAMA. 2020; 323(11):1061-1069. DOI: 10.1001/jama.2020.1585

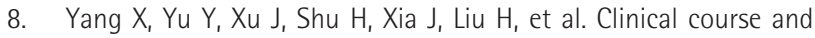
outcomes of critically ill patients with SARS-CoV-2 pneumonia in Wuhan, China: a single-centered, retrospective, observational study. Lancet Respir Med. 2020;8(5):475-81. D0I: 10.1016/S22132600(20)30079-5

9. Young BE, Ong SWX, Kalimuddin S, Low JG, Tan SY, Loh J, et al. Epidemiologic Features and Clinical Course of Patients Infected With SARS-CoV-2 in Singapore. JAMA. 2020;323(15):1488-1494. DOI: 10.1001/jama.2020.3204

10. Zhou F, Yu T, Du R, Fan G, Liu Y, Liu Z, et al. Clinical course and risk factors for mortality of adult inpatients with COVID-19 in Wuhan, China: a retrospective cohort study. Lancet. 2020;395(10229):1054-62. DOI: 10.1016/S0140-6736(20)30566-3

11. Ji D, Zhang $D, X u J$, Chen Z, Yang T, Zhao P, et al. Prediction for Progression Risk in Patients with COVID-19 Pneumonia: the CALL Score. Clin Infect Dis. 2020. DOI: 10.1093/cid/ciaa414

12. Charlson M, Szatrowski TP, Peterson J, Gold J. Validation of a combined comorbidity index. Journal of clinical epidemiology. 1994;47(11):1245-51. DOI: 10.1016/0895-4356(94)90129-5

13. Aggarwal S, Garcia-Telles N, Aggarwal G, Lavie C, Lippi G, Henry BM. Clinical features, laboratory characteristics, and outcomes of patients hospitalized with coronavirus disease 2019 (COVID-19): Early report from the United States. Diagnosis (Berl). 2020;7(2):916. DOI: $10.1515 / d x-2020-0046$

14. Argenziano MG, Bruce $S L$, Slater $C L$, Tiao JR, Baldwin MR, Barr RG, et al. Characterization and clinical course of 1000 patients with coronavirus disease 2019 in New York: retrospective case series. BMJ. 2020;369:m1996. DOI: 10.1136/bmj.m1996

15. Cummings MJ, Baldwin MR, Abrams D, Jacobson SD, Meyer BJ, Balough EM, et al. Epidemiology, clinical course, and outcomes of critically ill adults with COVID-19 in New York City: a prospective cohort study. Lancet. 2020;395(10239):1763-1770. DOI: 10.1016/ S0140-6736(20)31189-2

16. Kang YJ. Mortality Rate of Infection With COVID-19 in Korea From the Perspective of Underlying Disease. Disaster Med Public Health Prep. 2020:1-3. DOI: 10.1017/dmp.2020.60

17. Lai CC, Wang CY, Wang YH, Hsueh SC, Ko WC, Hsueh PR. Global epidemiology of coronavirus disease 2019 (COVID-19): disease incidence, daily cumulative index, mortality, and their association with country healthcare resources and economic status. Int J Antimicrob Agents. 2020;55(4):105946. D0I: 10.1016/j.ijantimicag.2020.105946

18. Wang Z, Yang B, Li Q, Wen L, Zhang R. Clinical Features of 69 Cases with Coronavirus Disease 2019 in Wuhan, China. Clin Infect Dis. 2020;ciaa272. DOI: 10.1093/cid/ciaa272

19. Wu Z, McGoogan JM. Characteristics of and Important Lessons From the Coronavirus Disease 2019 (COVID-19) Outbreak in China: Summary of a Report of 72314 Cases From the Chinese Center for Disease Control and Prevention. JAMA. 2020. D0I: 10.1001/jama.2020.2648

20. Zhang J, Wang $X$, Jia $X$, Li J, Hu K, Chen G, et al. Risk factors for disease severity, unimprovement, and mortality in COVID-19 patients in Wuhan, China. Clin Microbiol Infect. 2020;26(6):767-72. DOI: 10.1016/j.cmi.2020.04.012

21. Gaye B, Fanidi A, Jouven X. Denominator matters in estimat- 
ing COVID-19 mortality rates. Eur Heart J. 2020;ehaa282. DOI: 10.1093/eurheartj/ehaa282

22. Piccininni M, Rohmann JL, Foresti L, Lurani C, Kurth $T$. Use of all cause mortality to quantify the consequences of covid-19 in Nembro, Lombardy: descriptive study. BMJ. 2020;369:m1835. DOI: 10.1136/bmj.m1835

23. Analysis on 54 Mortality Cases of Coronavirus Disease 2019 in the Republic of Korea from January 19 to March 10, 2020. J Korean Med Sci. 2020;35(12):e132. DOI: 10.3346/jkms.2020.35.e132

24. Zhang Z, Yao W, Wang Y, Long C, Fu X. Wuhan and Hubei COVID-19 mortality analysis reveals the critical role of timely supply of medical resources. J Infect. 2020;81(1):147-178. D0I: 10.1016/j. jinf.2020.03.018

25. Huang C, Wang $Y$, Li $X$, Ren L, Zhao J, Hu Y, et al. Clinical features of patients infected with 2019 novel coronavirus in Wuhan, China. Lancet. 2020;395(10223):497-506. DOI: 10.1016/S01406736(20)30183-5

26. Shi H, Han X, Jiang N, Cao Y, Alwalid O, Gu J, et al. Radiological findings from 81 patients with COVID-19 pneumonia in Wuhan, China: a descriptive study. Lancet Infect Dis. 2020;20(4):425-34. DOI: 10.1016/S1473-3099(20)30086-4

27. Zhu J, Ji P, Pang J, Zhong Z, Li H, He C, et al. Clinical characteristics of 3,062 COVID-19 patients: a meta-analysis. J Med Virol. 2020;10.1002/jmv.25884. DOI: 10.1002/jmv.25884

28. Zhu N, Zhang D, Wang W, Li X, Yang B, Song J, et al. A Novel Coronavirus from Patients with Pneumonia in China, 2019. N Engl J Med. 2020;382(8):727-33. DOI: 10.1056/NEJMoa2001017

29. Ai T, Yang Z, Hou H, Zhan C, Chen C, Lv W, et al. Correlation of Chest CT and RT-PCR Testing in Coronavirus Disease 2019 (COVID-19) in China: A Report of 1014 Cases. Radiology. 2020:200642. DOI: 10.1148/radiol.2020200642

30. Huang EP, Sung CW, Chen CH, Fan CY, Lai PC, Huang YT. Can computed tomography be a primary tool for COVID-19 detection? Evidence appraisal through meta-analysis. Crit Care. 2020;24(1):193. DOI: 10.1186/s13054-020-02908-4

31. Shoji H, Fonseca E, Teles G, Passos RBD, Yanata E, Silva MMA, et al. Structured thoracic computed tomography report for COVID-19 pandemic. Einstein (Sao Paulo). 2020;18:eED5720. DOI: 10.31744/ einstein_journal/2020ED5720

32. Yang W, Cao O, Oin L, Wang $X$, Cheng Z, Pan A, et al. Clinical characteristics and imaging manifestations of the 2019 novel coronavirus disease (COVID-19):A multi-center study in Wenzhou city, Zhejiang, China. J Infect. 2020;80(4):388-93. DOI: 10.1016/j. jinf.2020.02.016

33. Cao B, Wang Y, Wen D, Liu W, Wang J, Fan G, et al. A Trial of Lopinavir-Ritonavir in Adults Hospitalized with Severe Covid-19. N Engl J Med. 2020;382(19):1787-1799. DOI: 10.1056/NEJMoa2001282

34. Guastalegname M, Vallone A. Could chloroquine/hydroxychloroquine be harmful in Coronavirus Disease 2019 (COVID-19) treatment? Clin Infect Dis. 2020;ciaa321. DOI: 10.1093/cid/ciaa321

35. Intson K, Kumar S, Botta A, Neckles R, Leung C, Jawaid A. An independent appraisal and re-analysis of hydroxychloroquine treatment trial for COVID-19. Swiss Med Wkly. 2020;150:w20262. DOI:

\subsection{4/smw.2020.20262}

36. Mahevas $M$, Tran $V T$, Roumier $M$, Chabrol $A$, Paule $R$, Guillaud $C_{1}$ et al. Clinical efficacy of hydroxychloroquine in patients with covid-19 pneumonia who require oxygen: observational comparative study using routine care data. BMJ. 2020;369:m1844. DOI: 10.1136/bmj.m1844

37. Monzani A, Genoni G, Scopinaro A, Pistis G, Kozel D, Secco GG. QTC evaluation in COVID-19 patients treated with chloroquine/hydroxychloroquine. Eur J Clin Invest. 2020;50(6):e13258. D0I: 10.1111/ eci. 13258

38. Slomski A. No Benefit for Lopinavir-Ritonavir in Severe COVID-19. JAMA. 2020;323(20):1999. DOI: 10.1001/jama.2020.6793

39. Tang W, Cao Z, Han M, Wang Z, Chen J, Sun W, et al. Hydroxychloroquine in patients with mainly mild to moderate coronavirus disease 2019: open label, randomised controlled trial. BMJ. 2020;369:m1849. DOI: 10.1136/bmj.m1849

40. Cao J, Tu WJ, Cheng W, Yu L, Liu YK, Hu X, et al. Clinical Features and Short-term Outcomes of 102 Patients with Corona Virus Disease 2019 in Wuhan, China. Clin Infect Dis. 2020;ciaa243. DOI: 10.1093/cid/ciaa243 